九州大学学術情報リポジトリ

Kyushu University Institutional Repository

\title{
Pulsing Treatments of Abscisic Acid and Sucrose for Improving Postharvest Quality of Cut Lily Flowers
}

Geng, Xing Min

College of Landscape Architecture, Nanjing Forestry University

Liu, Jun

College of Landscape Architecture, Nanjing Forestry University

Li, Min

College of Landscape Architecture, Nanjing Forestry University

Okubo, Hiroshi

Laboratory of Horticultural Science, Department of Agro-environmental Sciences, Faculty of Agriculture, Kyushu University

他

https://doi.org/10.5109/1526319

出版情報：九州大学大学院農学研究院紀要. 60 (1)，pp.87-92，2015-02-27. Faculty of Agriculture， Kyushu University

バージョン :

権利関係 : 


\title{
Pulsing Treatments of Abscisic Acid and Sucrose for Improving Postharvest Quality of Cut Lily Flowers
}

\author{
Xing Min GENG ${ }^{1 *}$, Jun $\mathrm{LIU}^{1}$, Min $\mathrm{LI}^{1}$, Hiroshi OKUBO ${ }^{2}$ \\ and Yukio OZAKI ${ }^{3}$ \\ Laboratory of Agricultural Ecology, Department of Bioresource Sciences, \\ Faculty of Agriculture, Kyushu University, Fukuoka 811-2307, Japan \\ (Received October 31, 2014 and accepted November 14, 2014)
}

\begin{abstract}
Although it is often considered as a senescence phytohormone, abscisic acid (ABA) at low concentration together with sucrose as pulsing solution displayed preservative effect on cut lily flowers. In order to further clarify the preservation mechanism of ABA, the effects of ABA pretreatment on physiological index and ethylene release were investigated. The addition of $2 \mathrm{mg} \cdot \mathrm{L}^{-1} \mathrm{ABA}$ to sucrose increased proline content in petals. This result suggested that ABA application resulted in water stress of the cut flowers to some extent. However the pretreatment of the cut lilies with $\mathrm{ABA}$ at $2 \mathrm{mg} \cdot \mathrm{L}^{-1}$ delayed the degradation of soluble proteins, and promoted the activity of superoxide dismutase (SOD) enzyme, which decreased the damage to cells induced by reactive oxygen species (ROS). It was also found that the pretreatment with $2 \mathrm{mg} \cdot \mathrm{L}^{-1}$ ABA inhibited ethylene release.
\end{abstract}

Key words: abscisic acid, cut lily, ethylene, physiological index, postharvest quality

\section{INTRODUCTION}

Abscisic acid (ABA), as a senescence phytohormone, has been proved to be related to flower petal senescence in rose (Mayak and Halevy, 1972; Kumar et al., 2008) and carnation (Nowak and Veen, 1982). Higher ABA concentrations were found in short-lived cultivars compared to long-lived rose cultivars (Halevy and Mayak, 1975). Exogenous application of ABA leads to enhancement of aging-related process in daffodil petals (Hunter et al., 2004).

$\mathrm{ABA}$, as one of the preservation agents, was also applied in the fresh-keeping of cut roses (Kohl and Rundle, 1972), Baccara roses (Pompodakis and Joyce, 2003; Pompodakis et al., 2004) and Eustoma flowers (Shimizu-Yumoto and Ichimura, 2009). ABA prolongs the vase life of cut roses with leaves, but shortens the vase life of leafless cut roses (Halevy et al., 1974). ABA can regulate water balance of cut flower through controlling stomata opening, increase the postharvest quality, and extend the vase life of cut flowers (Kohl and Rundle, 1972; Pompodakis and Joyce, 2003; Pompodakis et al., 2004). On the other hand it has been reported that ABA regulates water balance through ways other than stomata opening regulation (Borohov et al., 1976), the application of ABA did not affect the transpiration (Ichimura and Shimizu-Yumoto, 2007). ABA treatment can allevi-

College of Landscape Architecture, Nanjing Forestry University, Nanjing 210037, Jiangsu Province, People's Republic of China

${ }^{2}$ Laboratory of Horticultural Science, Department of Agroenvironmental Sciences, Faculty of Agriculture, Kyushu University, Fukuoka 812-8581, Japan

${ }^{3}$ Laboratory of Agricultural Ecology, Department of Bioresource Sciences, Faculty of Agriculture, Kyushu University, Fukuoka 811-2307, Japan

* Corresponding author (E-mail: xmgeng@njfu.edu.cn) ate the sucrose-induced leaf chlorosis and improve the quality of cut flowers (Pompodakis and Joyce, 2003; Shimizu-Yumoto and Ichimura, 2009).

Lilies are the world famous cut flowers with high ornamental value. Yang et al. (1996) indicated that ABA probably is the main factor affecting senescence of cut lilies, because morphology of cut flowers showed senescence symptoms following the peak of ABA, while ethylene can accelerate the aging process only to a certain extent. But Li et al. (2012) indicated that the addition of lower concentrations of ABA with sucrose and 8-hydroxyquinoline citrate (8-HQC) induced the increase of fresh weight, and partly alleviate the sucrose-induced leaf yellowing.

Based on the above researches, the preservation mechanism of ABA in cut lilies is still not clear. Lilium 'Sorbonne' (Oriental hybrid group) was used as an experimental material in this study to observe the preservation effect of $\mathrm{ABA}$, and to confirm further the preservation mechanism of ABA by determining the physiological indices and ethylene release of cut 'Sorbonnes' petals during postharvest.

\section{MATERIALS AND METHODS}

\section{Plant material}

Oriental hybrid lily cultivar 'Sorbonne', a harvest of Dounan, Kunming City, China, was used in this study. After harvesting, the cut flowers were shipped by air to Nanjing on the same day. The cut ends of the stems were immersed in tap water, and the flowers were stored at $20^{\circ} \mathrm{C}$ overnight. On the next day the stems were re-cut before the pulsing treatment. The stems were $30 \mathrm{~cm}$ high, and only one flower bud and three leaves at the top of the stem were used in the experiment. 


\section{Pulse treatment}

The stems were placed in glass jars containing various pretreatment solutions (Table 1) and $12 \mathrm{~cm}$ of the stems were dipped in the pretreatment solutions. Pulsing treatments were carried out for 18 hours at room temperature. After the treatments, the cut flowers were transferred to a postharvest evaluation room (day $21^{\circ} \mathrm{C} /$ night $14^{\circ} \mathrm{C}$, humidity $60 \%$, and fluorescent light $12 \mathrm{hr} /$ day).

Table 1. Pulsing solutions and corresponding number

\begin{tabular}{ll}
\hline Pretreatment & Composition of pretreatment solutions \\
\hline $\mathrm{CK} 1$ & DI water \\
$\mathrm{CK} 2$ & sucrose $+8-\mathrm{HQC}$ \\
$2 \mathrm{ABA}$ & sucrose $+8-\mathrm{HQC}+2 \mathrm{mg} \cdot \mathrm{L}^{-1} \mathrm{ABA}$ \\
$4 \mathrm{ABA}$ & sucrose $+8-\mathrm{HQC}+4 \mathrm{mg} \cdot \mathrm{L}^{-1} \mathrm{ABA}$ \\
$10 \mathrm{ABA}$ & sucrose $+8-\mathrm{HQC}+10 \mathrm{mg} \cdot \mathrm{L}^{-1} \mathrm{ABA}$ \\
$2 \mathrm{ABA}$ & sucrose $+8-\mathrm{HQC}+20 \mathrm{mg} \cdot \mathrm{L}^{-1} \mathrm{ABA}$ \\
$50 \mathrm{ABA}$ & sucrose $+8-\mathrm{HQC}+50 \mathrm{mg} \cdot \mathrm{L}^{-1} \mathrm{ABA}$
\end{tabular}

Notes: Concentrations of 8-hydroxyquinoline citrate (8-HQC) and sucrose were $200 \mathrm{mg} \cdot \mathrm{L}^{-1}$ and $30 \mathrm{~g} \cdot \mathrm{L}^{-1}$ respectively.

\section{Evaluation of flower and foliage vase-life}

In the evaluation room, the stems were placed in glass jars containing $500 \mathrm{ml}$ of distilled water, water level was $12 \mathrm{~cm}$ in height. During the postharvest evaluation, the number of chlorotic or senescent leaves and the inflorescence longevity were recorded every day.

\section{Measurement of fresh weight of cut stems and diameter of flowers}

Fresh weight and diameter of the flowers of 10 cut stems were measured every day. The flowers with diameter smaller than $10 \mathrm{~cm}$ at opening were excluded from the measurement. The change rate of fresh weight was calculated as the following:

Change rate of fresh weight $=\left(\mathrm{W}_{\mathrm{n}}-\mathrm{W}_{1}\right) / \mathrm{W}_{1} \times 100 \%$

Where $\mathrm{W}_{\mathrm{n}}$ is the weight of branch on the $\mathrm{n}$ day of vase days, and $\mathrm{W}_{1}$ is the fresh weight on the first vase day.

\section{Determination of proline, MDA, soluble proteins and SOD activity}

After the pulsing treatment, the inner perianths for the determination of these indices were sampled every other day and stored at $-80^{\circ} \mathrm{C}$ until analysis. Proline was determined by the specific colorimetric method at $515 \mathrm{~nm}$, which measures the red and stable product from reaction of proline and hydrindantin dehydrate under acidic conditions. Malondialldehyde (MDA) was determined by the method of thiobarbituric acid (TBA) as previously described (Geng et al., 2009). The content of soluble proteins was determined according to the method of Bradford (1976) using bovine serum albumin as the standard. Samples were prepared for superoxide dismutase (SOD) enzyme analyses by homogenizing $0.3 \mathrm{~g}$ of frozen samples in $5 \mathrm{ml}$ of an ice-cold $50 \mathrm{mM}$ sodium phosphate buffer ( $\mathrm{pH}$ 7.8). The extract was centrifuged at $4^{\circ} \mathrm{C}$ for $20 \mathrm{~min}$ at $12500 / \mathrm{g}$. The supernatant was then used for enzyme assays. Total activity of SOD in the extract was determined by measuring the inhibition in the photochemical reduction of nitroblue tetrazolium (NBT). One enzyme unit was defined as the amount of enzyme required to cause $50 \%$ inhibition of the rate of NBT reduction measured at $560 \mathrm{~nm}$. Three replicates were performed for all measurements. The experiments were repeated twice.

\section{Endogenous ethylene production}

From the first day in the vase period until senescence, samples for ethylene detection were taken five times. $10 \mathrm{~g}$ of the inner and outer fresh perianths were sealed individually in $250 \mathrm{ml}$ jars for $4 \mathrm{hr}$. Three $100 \mu \mathrm{L}$ gas samples were then removed via syringe from each jar and injected into a gas chromatograph fitted with a flame ionization detector (Shimadzu GC2010, Kyoto, Japan) and capillary column (Shimadzu SE-54, $30.0 \mathrm{~m} \times 0.32 \mathrm{~mm}$ $\times 0.25 \mu \mathrm{m}$, Kyoto, Japan). Ethylene was analyzed as described in Liu et al. (2006).

\section{RESULTS}

Effects of pulsing solutions containing different concentrations of ABA on the vase life and postharvest quality.

Vase life of the control (CK1) was 9.2 days, and the flowering rate was $75 \%$ with the average diameter of $14.2 \mathrm{~cm}$ (Table 2). Days to anthesis were 7.2 , and the vase life of the leaves was 8.4 days. The addition of sucrose and 8-HQC into the pulsing solution (CK2) did not affect the vase life of cut flowers significantly, and shortened the vase life of leaves, but quickened the flower opening, increased the flowering rate to $100 \%$ and the size of the opened flowers. The addition of $2 \mathrm{mg} \cdot \mathrm{L}^{-1} \mathrm{ABA}$ on the basis of CK2 did not affect the vase life of cut flowers, but increased the flower size and prolonged vase life of the leaves. The application of higher concentration of ABA promoted cut buds to open more quickly, and shortened the vase lives of the flowers and leaves.

Fresh weight of cut stems increased at first, and then decreased during the vase period. CK2 treatment slowed down the decreasing rate of the fresh weight. Lower concentration of $\mathrm{ABA}$ (including $2 \mathrm{mg} \cdot \mathrm{L}^{-1}$ and $4 \mathrm{mg} \cdot \mathrm{L}^{-1}$ $\mathrm{ABA}$ ) kept increasing fresh weight until the 5th day, whereas that of the control (CK1) and CK2 did until the 3rd day (Fig. 1). Although $50 \mathrm{mg} \cdot \mathrm{L}^{-1} \mathrm{ABA}$ induced the rapid and great increase of fresh weight at the beginning of the vase period, but the fresh weight began to rapidly decrease on the 4 th day.

\section{Effect of sucrose and ABA pre-treatments on} physiological index in cut petals

Effects of sucrose and ABA pretreatments on content of MDA and proline in petals

Proline, an effective osmotic adjustment substance, exhibits the water stress level of plants. The content of 
Table 2. Effects of different concentrations of ABA pulsing treatments on the vase life and the postharvest quality

\begin{tabular}{lccccc}
\hline Pre-treatment & $\begin{array}{c}\text { Rate of } \\
\text { flowering } \\
(\%)\end{array}$ & $\begin{array}{c}\text { Vase life of } \\
\text { flowers } \\
\text { (days) }\end{array}$ & $\begin{array}{c}\text { Diameter of } \\
\text { opened flowers } \\
(\mathrm{cm})\end{array}$ & $\begin{array}{c}\text { Days to } \\
\text { anthesis }\end{array}$ & $\begin{array}{c}\text { Vase life of } \\
\text { leaves } \\
\text { (days) }\end{array}$ \\
\hline $\mathrm{CK} 1$ & 75 & $9.2 \pm 1.83^{\mathrm{z}}$ & $14.2 \mathrm{c}^{\mathrm{y}}$ & $7.2 \pm 2.86^{\mathrm{z}}$ & $8.4 \pm 2.30^{\mathrm{z}}$ \\
$\mathrm{CK} 2$ & 100 & $9.8 \pm 1.58$ & $16.6 \mathrm{abc}$ & $6.8 \pm 2.49$ & $7.7 \pm 0.95$ \\
$2 \mathrm{ABA}$ & 100 & $9.5 \pm 1.07$ & $19.1 \mathrm{a}$ & $6.9 \pm 1.89$ & $9.3 \pm 1.39$ \\
$4 \mathrm{ABA}$ & 100 & $8.5 \pm 1.31$ & $17.9 \mathrm{ab}$ & $5.3 \pm 1.16$ & $7.0 \pm 1.77$ \\
$10 \mathrm{ABA}$ & 100 & $9.0 \pm 2.14$ & $16.7 \mathrm{abc}$ & $5.5 \pm 1.78$ & $7.4 \pm 1.82$ \\
$20 \mathrm{ABA}$ & 100 & $7.1 \pm 1.86$ & $16.1 \mathrm{bc}$ & $5.4 \pm 1.40$ & $6.6 \pm 2.23$ \\
$50 \mathrm{ABA}$ & 100 & $6.1 \pm 1.07$ & $16.1 \mathrm{bc}$ & $5.0 \pm 1.15$ & $5.5 \pm 1.52$ \\
\hline
\end{tabular}

${ }^{z}$ Values \pm standard deviation.

${ }^{y}$ Different letters in the same column means significant differences at the level of $\mathrm{P}<5 \%$.

The flowers whose biggest diameter was smaller than $10 \mathrm{~cm}$ were regarded as not flowering.

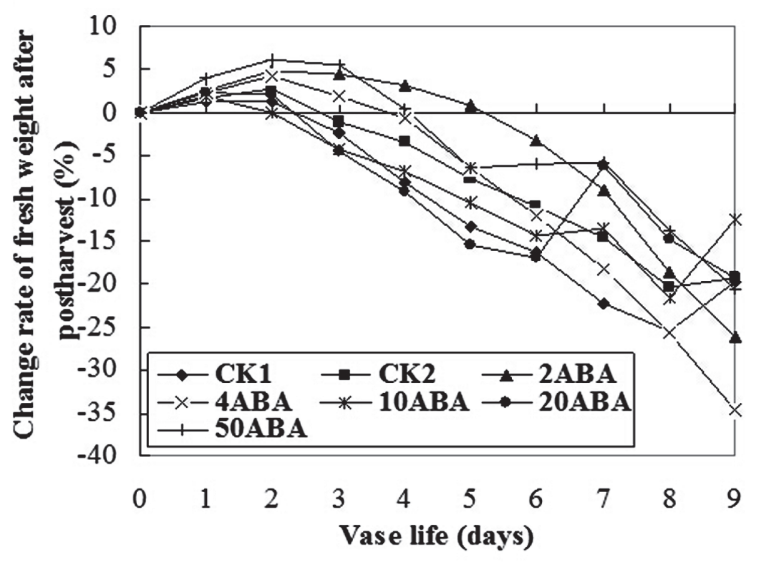

Fig. 1. Effects of pulsing solutions containing different concentrations of abscisic acid (ABA) on fresh weight of cut stems. CK1, CK2, 2 ABA, 4 ABA, 10 ABA, 20 ABA and 50 $\mathrm{ABA}$ in the figure indicate different pulsing solutions (CK1: cut flowers without pretreated; CK2: cut flowers pretreated with sucrose + 8-HQC solution; $2 \mathrm{ABA}, 4 \mathrm{ABA}$, $10 \mathrm{ABA}, 20 \mathrm{ABA}$ and $50 \mathrm{ABA}$ : cut flowers pretreated with sucrose + 8-HQC + different concentration of ABA solution).

proline gradually increased along with the aging of cut flowers (Fig. 2). Proline content in $50 \mathrm{mg} \cdot \mathrm{L}^{-1} \mathrm{ABA}$ pretreatment during the vase period was highest, secondly in $2 \mathrm{mg} \cdot \mathrm{L}^{-1} \mathrm{ABA}$ pretreatment. And the content in $2 \mathrm{mg} \cdot \mathrm{L}^{-1} \mathrm{ABA}$ had a rapid decrease on the 3rd day, and then increased with the aging of cut flowers. The content of proline in CK1 was the lowest and relatively stable at the primary stage of the postharvest evaluation, increased prior to senescence. Proline content in CK2 was in between ABA treatment and CK1. The results suggested that the addition of lower ABA with sucrose did not alleviate the degree of water deficit stress in cut flowers.

MDA is commonly used as an indicator in the aging and resistance physiology. The accumulation of MDA exacerbates the damage to the plasma membrane and also reflects the lipid peroxidation level. As shown in Fig. 3 , the content of MDA in each treatment gradually

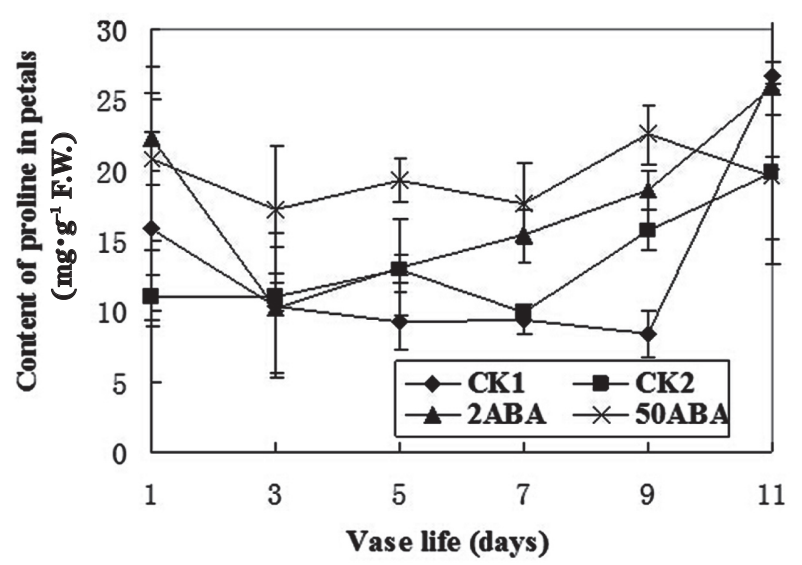

Fig. 2. Effects of sucrose and abscisic acid (ABA) pretreatments on content of proline in the petals. CK1, CK2, 2 $\mathrm{ABA}$ and $50 \mathrm{ABA}$ in the figure indicate different pulsing solutions (CK1: cut flowers without pretreated; CK2: cut flowers pretreated with sucrose +8 -HQC solution; 2 ABA and 50 ABA: cut flowers pretreated with sucrose + $8-\mathrm{HQC}+2 \mathrm{mg} \cdot \mathrm{L}^{-1}$ or $\left.50 \mathrm{mg} \cdot \mathrm{L}^{-1} \mathrm{ABA}\right)$. Data are expressed as mean $\pm \mathrm{SE}$ triplicate assays. Vertical bars represent the standard errors of the means.

increased along with the aging of cut flowers, except that MDA content in CK1 on the 5th day reached highest. There were no large differences in MDA content at the beginning of the vase period, only on the 11th day before the aging of cut flowers the content differed significantly among the treatments, and MDA content in $50 \mathrm{mg} \cdot \mathrm{L}^{-1}$ ABA was the highest, followed by CK1, CK2 and $2 \mathrm{mg} \cdot \mathrm{L}^{-1} \mathrm{ABA}$ were the lowest.

Effects of sucrose and ABA pretreatments on the activity of $S O D$ in petals

Plants under stress will produce a large number of reactive oxygen species (ROS), damage the structure of active oxygen scavengers and the membrane lipid. SOD may remove superoxide anion free radical $\left(\mathrm{O}^{2-}\right)$, and protect the membrane structure of cut petals. During the vase period the activity of SOD enzyme in petals pretreated with different pulsing solutions showed different change trends (Fig. 4). SOD activity in CK1 and CK2 


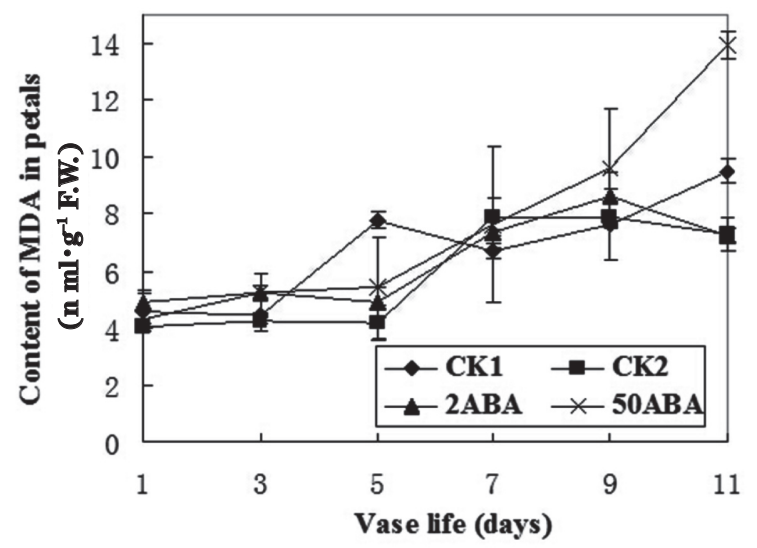

Fig. 3. Effects of sucrose and abscisic acid (ABA) pretreatments on content of malondialldehyde (MDA) in the petals. CK1, CK2, $2 \mathrm{ABA}$ and $50 \mathrm{ABA}$ in the figure indicate different pulsing solutions (CK1: cut flowers without pretreated; CK2: cut flowers pretreated with sucrose + 8-HQC solution; $2 \mathrm{ABA}$ and $50 \mathrm{ABA}$ : cut flowers pretreated with sucrose $+8-\mathrm{HQC}+2 \mathrm{mg} \cdot \mathrm{L}^{-1}$ or $50 \mathrm{mg} \cdot \mathrm{L}^{-1}$ $\mathrm{ABA}$ ). Data are expressed as mean $\pm \mathrm{SE}$ triplicate assays. Vertical bars represent the standard errors of the means.

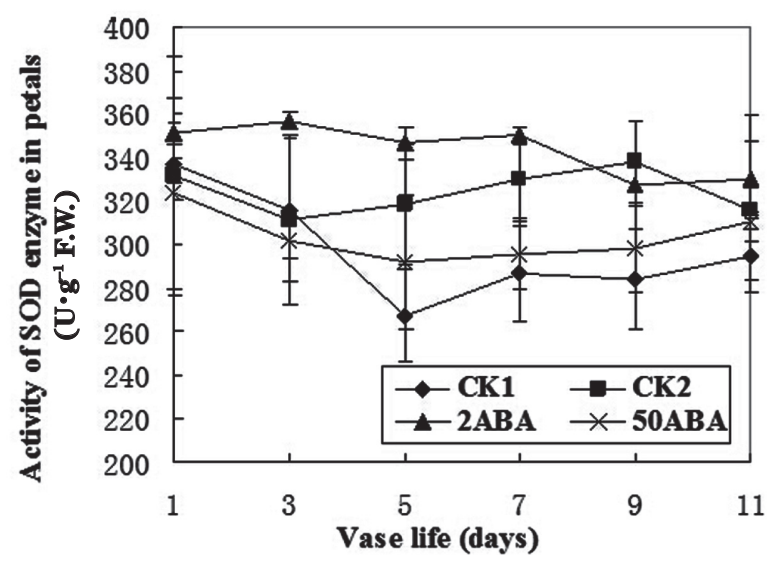

Fig. 4. Effects of sucrose and abscisic acid (ABA) pretreatments on the activity of superoxide dismutase (SOD) in the petals. CK1, CK2, $2 \mathrm{ABA}$ and $50 \mathrm{ABA}$ in the figure indicate different pulsing solutions (CK1: cut flowers without pretreated; CK2: cut flowers pretreated with sucrose + 8-HQC solution; $2 \mathrm{ABA}$ and $50 \mathrm{ABA}$ : cut flowers pretreated with sucrose $+8-\mathrm{HQC}+2 \mathrm{mg} \cdot \mathrm{L}^{-1}$ or $50 \mathrm{mg} \cdot \mathrm{L}^{-1}$ $\mathrm{ABA}$ ). Data are expressed as mean $\pm \mathrm{SE}$ triplicate assays. Vertical bars represent the standard errors of the means.

decreased at the beginning of the vase period followed by a small increase, then decreased again. SOD activity in both $\mathrm{ABA}$ pretreatment slowly declined during the vase period. Overall, SOD activity in CK1 and $50 \mathrm{mg} \cdot \mathrm{L}^{-1} \mathrm{ABA}$ pretreatment was lower than that in CK2, the addition of $2 \mathrm{mg} \cdot \mathrm{L}^{-1} \mathrm{ABA}$ based on CK2 further promoted the activity of SOD enzyme and protected the integrity of membrane structure of petals.

Effects of sucrose and ABA pretreatments on content of soluble proteins in petals

As shown in Fig. 5, the content of soluble proteins decreased gradually with the opening and aging of cut flowers. There were no significant differences in the con-

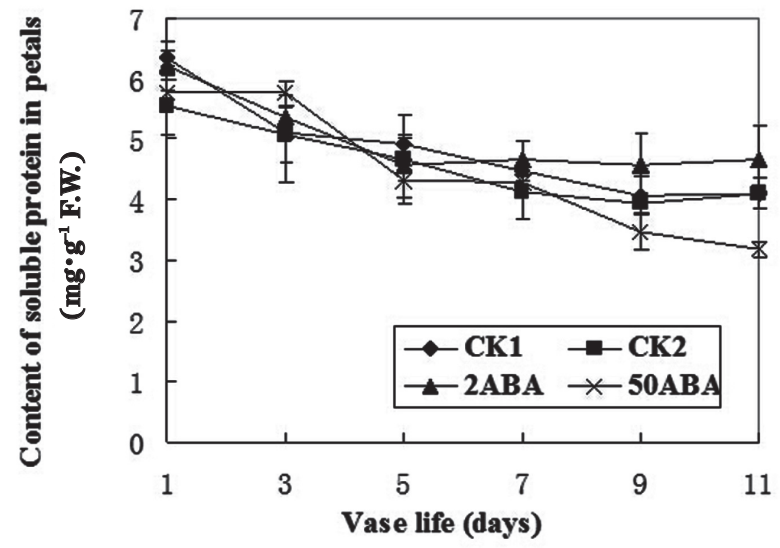

Fig. 5. Effects of sucrose and abscisic acid (ABA) pretreatments on content of soluble proteins in the petals. CK1, $\mathrm{CK} 2,2 \mathrm{ABA}$ and $50 \mathrm{ABA}$ in the figure indicate different pulsing solutions (CK1: cut flowers without pretreated; CK2: cut flowers pretreated with sucrose + 8-HQC solution; $2 \mathrm{ABA}$ and $50 \mathrm{ABA}$ : cut flowers pretreated with sucrose $+8-\mathrm{HQC}+2 \mathrm{mg} \cdot \mathrm{L}^{-1}$ or $\left.50 \mathrm{mg} \cdot \mathrm{L}^{-1} \mathrm{ABA}\right)$. Data are expressed as mean $\pm \mathrm{SE}$ triplicate assays. Vertical bars represent the standard errors of the means.

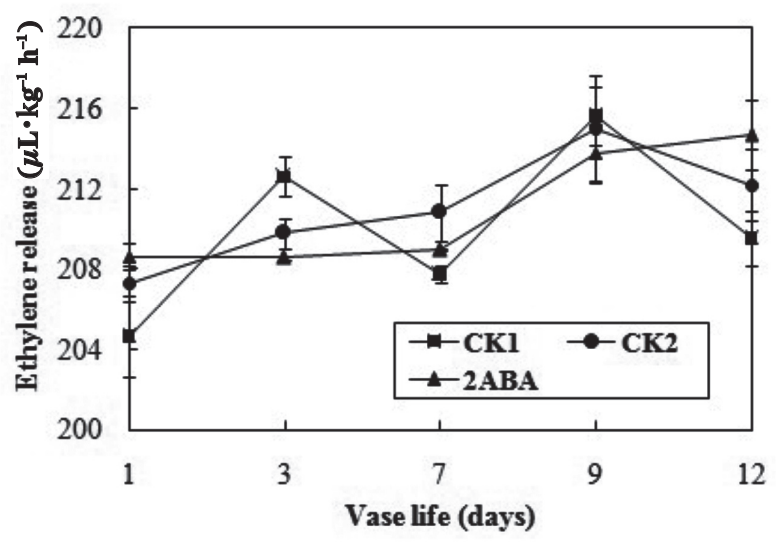

Fig. 6. Effects of sucrose and abscisic acid (ABA) pretreatments on ethylene release of cut 'Sorbonnes' petals. CK1, CK2 and $2 \mathrm{ABA}$ in the figures indicate different pulsing solutions (CK1: cut flowers without pretreated; CK2: cut flowers pretreated with sucrose + 8-HQC solution; 2 ABA: cut flowers pretreated with sucrose+ $\left.8-\mathrm{HQC}+2 \mathrm{mg} \cdot \mathrm{L}^{-1}\right)$. Data are expressed as mean $\pm \mathrm{SE}$ triplicate assays. Vertical bars represent the standard errors of the means.

tent of soluble proteins among these pretreatments until the 7th day in the vase period. From the 7th day the content of soluble proteins in petals pretreated with sucrose and $50 \mathrm{mg} \cdot \mathrm{L}^{-1} \mathrm{ABA}$ decreased, those in petals pretreated with only sucrose (CK2) or water (CK1) decreased slowly, but those in petals pretreated with sucrose and $2 \mathrm{mg} \cdot \mathrm{L}^{-1} \mathrm{ABA}$ did not change significantly. The results indicated that the pretreatment of $2 \mathrm{mg} \cdot \mathrm{L}^{-1} \mathrm{ABA}$ and sucrose slowed down the degradation of soluble proteins in petals.

Effects of sucrose and ABA pretreatments on ethylene release of cut petals 
There were two significant rises in ethylene production in CK1 petals during the vase life, respectively on the 3rd day and the 9th day (Fig. 6). The application of sucrose (CK2) induced the higher ethylene production on the first day of the vase life, but the peak in ethylene concentration was not observed until the 9th day, and then decreased. Ethylene release of cut petals pretreated with $\mathrm{ABA}+\mathrm{Suc}(2 \mathrm{ABA})$ increased gradually, no obvious peak appeared during the vase life, and the concentration of ethylene was lower than that in the other two pretreatment except that it was slightly higher before the senescence. The results indicated the pretreatment of sucrose inhibited the appearance of ethylene peak at the opening of cut flowers, and the addition of $2 \mathrm{mg} \cdot \mathrm{L}^{-1}$ $\mathrm{ABA}$ based on the sucrose had the further inhibition on ethylene release.

\section{DISCUSSION}

It was found in our study that the pulsing treatment of sucrose and 8-HQC did not affect the vase life of cut flowers significantly, but increased their flowering rate, and promoted the increase in fresh weight and the size of the flowers (Table 1 and Fig. 1). The addition of sugar to the vase solution did not overcome the reduced longevity induced by cold storage, but promoted more flowers to open fully (Han, 2003). Song et al. (1996) also found that the use of sucrose and 8-hydroxyquinoline sulfate (HQS) in the vase solution induced opening of more floral buds than in the water control, especially when flower buds were harvested earlier.

The pulsing treatment of sucrose and 8-HQC resulted in leaf yellowing, and shortened the vase life of cut leaves (Table 1 and Fig. 1). The adverse effect of the sucrose and antimicrobial was also reported when they were used in the vase solution, especially the concentration of sucrose was higher (Nowak and Mynett, 1985; Han, 2003). Van Doorn (2008) indicated the leaf yellowing resulted from sucrose, not from the antimicrobial. The sucrose-induced leaf chlorosis of cut lilies can be overcome by a spray treatment with $\mathrm{GA}_{4+7}$ and BA (Han, 2003), or by pulsing treatment with $\mathrm{GA}_{3}$ (Nowak and Mynett, 1985). Since leaf yellowing induced by sucrose pulse treatment during our study may not be as serious as applied with vase solution, the addition of sucrose into pulsing solution affected the postharvest quality of cut leaves. The addition of lower concentration of ABA with sucrose and 8-HQC alleviated the sucrose-induced leaf chlorosis. Similar results have been reported in cut Eustoma flowers and cut 'Baccara' roses (Pompodakis and Joyce, 2003; Shimizu-Yumoto and Ichimura, 2009).

The addition of lower concentration of ABA with sucrose and 8-HQC did not affect the vase life of cut flowers, but induced the rapid opening of floral buds and the increase in the size of opened flowers, especially the application of $2 \mathrm{mg} \cdot \mathrm{L}^{-1} \mathrm{ABA}$ (Table 1 and Fig. 1). This may be related to the delayed degradation of soluble proteins (Fig. 4) and the promoted uptake of sucrose from the pulsing solution (data not shown). The application of $\mathrm{ABA}$ resulted in the decrease in protein content in rose petals (Borochov et al., 1976), in our study higher ABA gave rise to the rapid degradation of soluble proteins. Therefore, the effect of ABA application on the content of soluble proteins in cut petals might be related to the concentrations of applied ABA. In addition, there was a significant increase in the content of soluble sugars in petals after the plusing treatment with $2 \mathrm{mg} \cdot \mathrm{L}^{-1}$ $\mathrm{ABA}$ and sucrose, since no differences were observed during vase period (data not shown). But Ichimura and Shimizu-Yumoto (2007) also reported that ABA application reduced sucrose uptake from the pulsing solution.

A large number of reports suggested that ABA treatment could inhibit transpiration, and regulate water balance of cut flowers by stomatal closure (Kohl and Rundle, 1972; Pompodakis and Joyce, 2003; Pompodakis et al., 2004). But pulsing treatment of $2 \mathrm{mg} \cdot \mathrm{L}^{-1} \mathrm{ABA}$ increased proline content in petals, which was higher than that in CK1 and CK2 during vase life except the 3rd day. The results indicated that lower $\mathrm{ABA}$ induced a certain degree of water deficit stress. ABA did not regulate the water balance effectively. In the preservation of cut rose flowers, the inhibition of ABA on transpiration was not observed (Ichimura and Shimizu-Yumoto, 2007). Lower ABA did not affect the accumulation of MDA, but increased the activity of SOD enzyme. This suggested that pulsing treatment of lower ABA could remove $\mathrm{O}^{2-}$, protect cell membrane structural integrity of cut petals, maintain normal metabolism of cut flowers and delay the senescence of cut flowers.

Yang et al. (1996) indicated that ABA is the main factor affecting senescence of cut lily flowers, and ethylene could accelerate the aging process to a certain extent. In the study on senescence of cut roses, it has been reported that $\mathrm{ABA}$ treatment inhibited ethylene release, and accelerated the aging of cut flowers (Mayak and Halevy, 1972). In our study the pulsing treatment of lower ABA inhibited ethylene release, and delayed the aging of cut lilies. The results further suggested the preservation of lower ABA on cut lilies is not by regulating the water balance directly, but linked with the hormone balance of cut flowers.

\section{REFERENCES}

Borochov, A., S. Mayak and A. H. Halevy 1976 Combined effects of abscisic acid and sucrose on growth and senescence of rose flowers. Physiol. Plant., 36: 221-224

Borohov, A., T. Tirosh, and A. H. Halevy 1976 Abscisic acid content of senescing petals on cut rose flowers as affected by sucrose and water stress. Plant Physiol., 58: 175-178

Bradford M. M. 1976 A rapid and sensitive method for the quantitation of microgram quantities of protein utilizing the principle of protein-dye binding. Anal. Biochem., 72: 248-254

Geng, X. M., J. Liu, J. G. Lu, F. R. Hu and H. Okubo 2009 Effects of cold storage and different pulsing treatments on postharvest quality of cut OT lily 'Mantissa' flowers. J. Fac. Agr., Kyushu Univ., 54: 41-45

Halevy, A. H., S. Mayak, T. Tirosh, H. Spiegelstein and A. M. Kofranek 1974 Opposing effects of abscisic acid on senescence of rose flowers. Plant Cell Physiol., 15: 813-821

Halevy, A. H. and S. Mayak 1975 Interrelationship of several phytohormones in the regulation of rose petal senescence. Acta Hortic., 41: 103-116 
Han, S. S. 2003 Role of sugar in the vase solution on postharvest flower and leaf quality of Oriental lily 'Stargazer'. HortScience, 38: $412-416$

Hunter, D. A., A. Ferrante, P. Vernieri and M. S. Reid 2004 Role of abscisic acid in perianth senescence of daffodil (Narcissus pseudonarcissus 'Dutch Master'). Physiol. Plant., 121: 313321

Ichimura, K. and H. Shimizu-Yumoto 2007 Extension of the vase life of cut roses by treatment with sucrose before and during simulated transport. Bull. Natl. Inst. Flor. Sci., 7: 17-27

Kohl, H. C. and D. L. Rundle 1972 Decreasing water loss of cut roses with abscisic acid. HortScience, 7: 249

Kumar, N., G. C. Srivastava and K. Dixit 2008 Hormonal regulation of flower senescence in roses (Rosa hybrida L.). Plant Growth Regul., 55: 65-71

Li, M., X. M. Geng and J. Liu 2012 Effect of ABA and sucrose pretreatment on preservation of cut flowers in Lilium Orential 'Sorbonne'. China Forest. Sci. Tech., 26(2): 41-44 (in Chinese with English abstract)

Liu, Z. Y., C. Z. Shen and Y. Y. Dong 2006 Determination of ethylene release rate in rape by gas chromatography. Chem. \& Bioengineer., 2: 55-56 (in Chinese with English abstract)

Mayak, S. and A. H. Halevy 1972 Interrelationships of ethylene and abscisic acid in the control of rose petal senescence. Plant Physiol., 50: 341-346

Nowak, J. and K. Mynett 1985 The effects of sucrose, silver thiosulfate and 8-hydroxyquinoline citrate on the quality of
Lilium inflorescences cut at the bud stage and stored at low temperature. Scientia Hortic., 25: 299-302

Nowak, J. and H. Veen 1982 Effects of silver thiosulfate on abscisic acid content in carnations as related to flower senescence. Plant Growth Regul., 1: 153-159

Pompodakis, N. E. and D. C. Joyce 2003 Abscisic acid analogue effects on the vase life and leaf crisping of cut Baccara roses. Australian J. Exp. Agric., 43: 425-428

Pompodakis, N. E., D. C. Joyce, L. A. Terry and D. E. Lydakis 2004 Effects of vase solution $\mathrm{pH}$ and abscisic acid on the longevity of cut 'Baccara' roses. J. Hort. Sci. Biotech., 79: 828-832

Shimizu-Yumoto, H. and K. Ichimura 2009 Abscisic acid, in combination with sucrose, is effective as a pulse treatment to suppress leaf damage and extend foliage vase-life in cut Eustoma flowers. J. Hort. Sci. Biotech., 84: 107-111

Song, C., C. Bang, S. Chung, Y. Kim, J. Lee and D. Lee 1996 Effects of postharvest pretreatments and preservation solutions on vase life and flower quality of Asiatic hybrid lilies. Acta Hortic., 414: 277-285

Van Doorn, W. G. 2008 Is the onset of senescence in leaf cells of intact plants due to low or high sugar level? J. Exp. Bot., $\mathbf{5 9}$ 1963-1972

Yang, Q. S., X. S. Huang, Y. Ji, S. L. He and H. Y. Song 1996 Effects of different temperature storage on changes of endogenous hormone levels in cut lily. Acta Agriculturae Universitatis Henanensis, 30(3): 203-207 (in Chinese with English abstract) 